Historic, archived document

Do not assume content reflects current scientific knowledge, policies, or practices. 



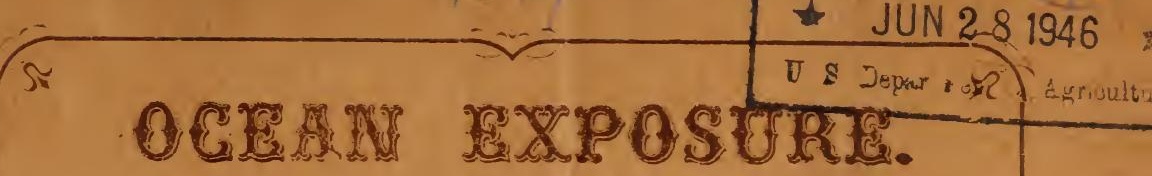

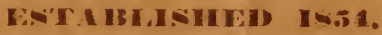

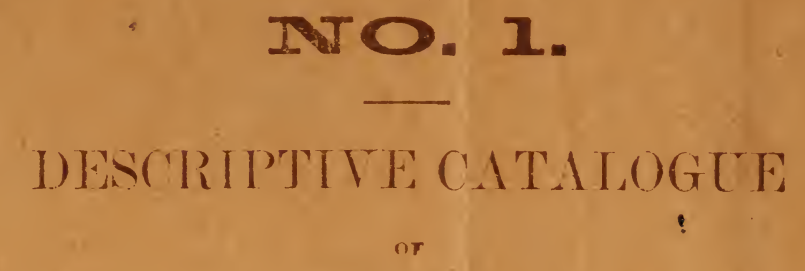

FRUIT AND ORNAMENTAL

TREES，

Small Fruits, Flowering Shrubs, Vines, \&c.

ITLTIVATFI ANT FOR SALE AT THE:

RUMSON NURSERIES

RED P.INK, MONMOLTH CO., N. J.

\section{A. HANCE \& SON,

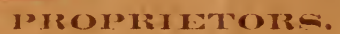

A.HER HIXCE.

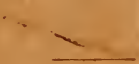

BENJ. B. HAYCE.

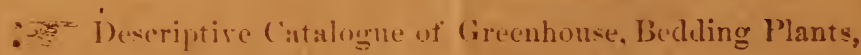
ire sent on application.

RIT) BANK, N. J.:

J. R. NGLING, PRINTEH.

25

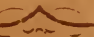




\section{A RULE TO FIND}

\section{THE NUMBER OF PLANTS REQUIRED FOR AN ACRE}

Multiply the width by the breadth, and see how many times this number is contained in 43,560 , the number of square feet in an acre. For instance plants set $3 \times 5$ feet, each plant would require 15 square feet; 43,560 divided by 15 would give 2,904 plants to the acre.

\section{DISTANCE TO PLANT.}

Standard Apple Trees,

“ Cherry and Pear Trees,

Dwarf Apple and Quince Trees,

" Pear Trees,

Peach and Plum Trees,

Gooseberries,

66

Currants,

6

Blackberries, “

Raspberries, Strawberries,

-

Asparagus,
25 to 30 feet each way. 15 “ 25 10 " 12 8 " 10 16 " 20

\section{THE NUMBER OF PLANTS REQUIRED PER ACRE AT THE FOLLOWING DISTANCES:}

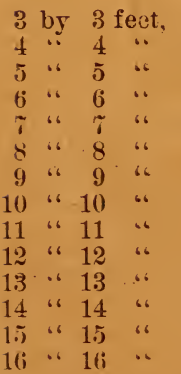

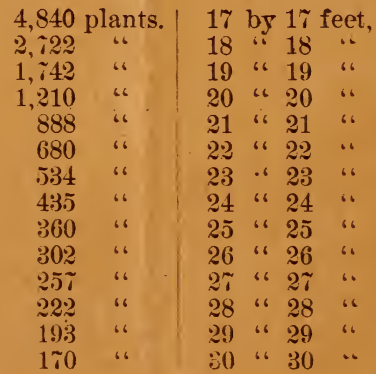

150 plants.

134 ".

$120 \quad$ “

108 " “

98 ،

90 "

82

i5

69

64

59

55

51 “

48 . 


\section{CONDITIONS.}

Customers who do not comply strictly with our instructions for transplanting, must take the responsibility of their success entirely upon themselves.

To parties not familiar with varieties, we should like an expression as to the general qualities required, after which, if they will leave the selections to us, we will certainly come nearer to their wishes than any efforts they might attempt.

Orders amounting to $\$ 25$ and upward, DELIVERED within 5 to 8 miles of the Nursery without extra charge, our croice of time.

We make a moderate charge for packing on articles enumerated in this Catalogue, and forwarded to any place desired at the expense and risk of the purchaser, after delivery to our nearest clepot.

Then losses occur by detentions, claims should at once be made on the forwarders.

TERxs-Cash, without a spccial agreement to the contrary; reference required from strangers. Bills renclered and settlements required on the first day of January and July witliout regard to date of purchase.

\section{OBSERVE.}

These Nurseries have an ocean exposure, consequently the trees will readily acclimate to any situation, as very few localities are more exposed.

All interested in Horticulture and Pomology are invited to visit the grounds during the growing season.

Our close proximity to the city of New York as a shipping point we are assured is justly appreciated by those living at distant points along the coast; in consideration of freighting by ressels, being a saving of serentyfive per cent. as compared with transportation by rail.

\section{REMARKS.}

CoRrespoxdexts will confer a mutual favor by writing their Name, Post-office, County, and State legibly, and more particularly their name; we can make out almost any hand concerning matters that we have heard of before, but a new correspondent's signature frequently passeth all understanding.

It being impossible for any establishment to grow the varieties in such proportions as will meet all orders, a number of the responsible nurseries are visited early in the season to make selections from which to draw a supply; consequently all seasonable orders can be filled as desired. Nerertheless, Peach Trees, ornamental and green-house stock are specialties.

The specimen Orchards are extensive, and deteriotated varieties are diligently rejected.

Some of the most highly recommended varieties of fruit are produced by trees of feeble and irregular growth, consequently customers must not expect the trees of all rarieties to be equally large and fine. 


\section{TRANSPLANTING.}

If the trees are frozen when received, do not unpack them, but bury the whole package, or place it in a cool cellar until they are thawed; if thawed by exposure to the sun or air their vitality is destroyed.

The planting season is not regulated by any particular month or day, nor by the state of vegetation where the planting is to be done, but by the dormant condition of the trees. Hence, trees can be sent with safety from these Nurseries to localities several degrees South, even if they do not arrive until the ordinary transplanting season of that locality has passed.

Southern orders should be received by November 20th, to insure Fall shipment.

Transplanting should receive your undivided attention. It takes but a little time in comparison with the benefits derived. Cut back the limbs of the tree when received at least one-half to one-third their length, and with peach trees leave between two and three inches next to the main stem.

Do not expose the roots unnecessarily-trenching such as you have not time to set within thirty minutes at least.

This latter injunction should be more generally obeyed; some may suppose they took every care in planting, when perhaps the trees were all: dropped near their places and exposed to the sun and dry winds twentyfour hours or more before planting, and by the time the last were reached they were beyond redemption, except by plumping, which operation is next explained.

In consequence of occasional delays in transportation, more or less trees in the package may become too dry or shriveled; all such should be buried at once, root and branch, in moist soil, for ten days, or until they plump, whent hey will grow as well as any; but if set without this preparar tion, they will be worthless.

Proceeding to plant, the hole should be large enough to admit of eacht root being drawn out to its natural position; then fill the crevices with finely pulverized earth, finishing off so that the tree will be no deeper than it grew in the nursery; then draw enough earth around the tree to make a mound of one foot in height, which can be worked away through the Summer, after the tree has become established. It would be advisable to raise this mound again in time to protect the tree the first Winter after the first Summer's growth.

\section{PRUNING STANDARDS.}

Orchardists that wish to form the head of the tree high enough to use. horse in their cultiration frequently trim up to fast, and consequently get a slender stem that weeps orer and makes an ill-shaped tree. The limbs 
for two to three feet below those intended for the main branches can be cut back for two or three years, and cut off by degrees when the stem has attained its proper proportions.

The subsequent pruning merely requires to cut back the disproportionate branches and keep the head well thinned out, so as to obviate the necessity of amputating large limbs at an advanced age.

For pruning dwarfs, see Dwarf Pears.

\section{CULTIVATION.}

The soil should be kept mellow and clear of weeds; see that the plow does not injure the roots, and plant thinly of corn or root crops for several years until the roots of the trees have the ascendency, when it can be seeded with clover; and let the crop fall in the ground, then turn in hogs or sheep to eat up and destroy the worms in the refuse falling fruit; this is absolutely essential to prevent the ruinous increase of insects.

Never allow broadcast grain crops to ripen in an orchard; where the ground washes or gullies through the Winter; they can be sown in the Fall, to be plowed under again in the Spring.

Successful fruit growers apply manure liberally; keep your land in good heart; use the various composts of the farm, also lime, ashes, bonedust, guano, phosphates, and the rest; nothing comes amiss. You would do all this for ordinary crops, why not for the fruit? It will be sure to pay. Spread it on broadcast to be plowed under, or otherwise, it will leach down and the roots will find it. Guano should be applied during a wet spell, or just before a shower.

In our various suggestions as to cultivation, etc., through the Catalogue, customers must not take it for granted that they must follow them to the letter, (except the instructions how to proceed with plants when received, and preparation for transplanting), as we have such a variety of soil and climate; they are merely general in their application, to gire the new beginner some ideas how to start, when a few years experience will enable him to make such improvements as may best appear; for instance, to cover a large field of strawberries with cornstalks or other mulch, to some would appear a great undertaking, and in some soils and situations it. might not pay; but try one hundred square feet.

\section{NOTICE.}

By unwearied personal attention to business, and through the co-operation of well-trained, skillful assistants employed in the various departments, the undersigned, acting member of the firm, is determined to give satisfaction, and would like to hear from all our customers of each lot sent out, trusting that they will consider when handling a tree or plant that they are dealing with life or death and will proceed accordingly. 


\section{CATALOGUE}

\section{OE MOST OF THE VARIETIES CULTIVATED.}

We do not propagate an endless variety of fruits, but diligently reject those that have become deteriorated-of which we have annual practical experience, as we have large specimen orchards.

Prices, except when noted, will be found on the last pages, all of which are occasionally subject to such variations as the prices current may demand, and for the ordinary size plants and trees at the Nursery.

\section{APPLES.}

SUMDIER.

Am. Summer Pearmain, Early Harvest,

Benoni, Bough Sweet, Early Joe, Early Hagloe,

Keswick Codlin, Nyack Pippin, Primate or Belle Rose, William's Farorite, Red Astrachan,

Summer Queen, Sops of Wine, Tetofsky, William's Farorite,
Wren's Egg.

AUTUMN.

Duchess of Oldenburgh, Hawthorn Den, Englistr Codlin, Fall Fippin,

Gravenstein, Jeffries,

Jersey Sweet, Lowell,

Golden Sweeting,

Maiden's Biush,

Orange Pippin,

Porter,

Rambo,

Spice,

St. Lawrence.

WINTER.

$\begin{array}{lll}\text { Am. Golden Russet, } & \text { Grimes Golden. } & \text { Peck's Pleasant, } \\ \text { Bailey's Sweet, } & \text { Golden Russet, } & \text { Rambo, } \\ \text { Belmont, } & \text { Hubbardson's Nonesuch, Rhode Island Greening, } \\ \text { Baldwin, } & \text { Irish Pippin, } & \text { Roman Stem, } \\ \text { Ben Daris, } & \text { Jersey Greening, } & \text { Roxbury Russet, } \\ \text { Broad Top, } & \text { King of Tompkins Co., Rome Beauty, } \\ \text { Canada Reinette, } & \text { Ladies'Swecting, } & \text { Smith's Cider, } \\ \text { Carthouse, } & \text { Lady Apple, } & \text { Spitzenberg Esopus, } \\ \text { Colrert, } & \text { Moore's Sweet, } & \text { Swarr, } \\ \text { Danrer's Sweet, } & \text { Monmouth Pippin, } & \text { Twenty Ounce, } \\ \text { English Russet, } & \text { Newtown Pippin, } & \text { Wagener. } \\ \text { Fallawater, } & \text { Northern Spy, } & \\ \text { French Pearmain, } & \text { Ortley, } & \end{array}$

CRAB APOLES.

Siberian Yellow and Red, for preserving.

The following Crab Apples are among our finest desert fruit: Acubifolia.

Hyslop,

Transcendant, \&rc.

\section{DYARPAPPLES}

Being grown more for: ornament than utility, we grow those most valued for their color and productiveness. Orders left to our selection, we trust will give satisfaction. 
AND ORNAMENTAL TREES, SHRUBS, \&C.

\section{STANDARD PEARS.}

\section{SUMMER.}

Ananas d'Ete,

Beurre Giffard, Bloodgood, Clapp's Favorite,

Andrews,

Bartlett,

Belle Lucrative,

Beurre d'Anjou,

Beurre Diel,

Beurre Bosc,

Buffum,

Beurre Clairgeau, Doyenne d'Alencon, Easter Beurre, $\begin{array}{ll}\text { Duch'se de Beurre d'Ete, Manning's Elizabeth, } \\ \text { Dlarborn's Seedling, } & \text { Osband's Summer, } \\ \text { Doyenne d'Ete, } & \text { Rostiezer, } \\ \text { Jargonelle, } & \text { Tyson. }\end{array}$

AUTUMN.

Duchess d'Angouleme, Onondaga, Flemish Beauty. Seckel, Howell, Henkel, Sheldon, Leache's Kingsessing, W Washington. Louise Bonne de Jersey, Marie Louise,

\section{WINTER.}

Glout Morceau, Josephine de Malines, Lawrence,
Vicar of Winkfield, Winter Nelis.

Such of the abore as sueceed on the qhince stock can be furnished as

\section{D}

The trees should be set eight feet apart each way, and but six feet in a single row. When preparing the ground, give it a liberal dressing from the barn-yard well decomposed with old sods, swamp muck or peat, adding lime, ashes, and other approved fertilizers at intervals. Set them one or two inches below the bud. As the roots of the Dwarf keep rery near the surface, keep them well mulched through the Summer with refuse leaves, weeds, or litter of any kind.

Begin the head eighteen to trrenty inches from the ground; cut them back every season, so as to form a close, compact head.

\section{PEACH TREES.}

The ground for an orchard. should be a sandy loam, and care should be taken that the subsoil is not too retentive of water. Place the trees sixteen to twenty feet apart each way. (See directions for setting and pruning in the beginning of Catalogue.) To insure success the ground must be thoroughly cultivated, and it must not be forgotten that it is always expensive business to raise weeds, and more particularly so in a Peach Orchard. The three first years after planting, the space between the trees may be moderately cropped, being careful to use some plant that will grow to the end of the season, among which Sweet Potatoes are the best.

The growing of Peach Trees for Orchardists and dealers as well as potted plants for the Peach House is a specialty, and we will sell at the market rates of regular Nurserymen; but the prices of those who are only occasional growers will not be any guide. 
We take special care to grow our stocks from seed collected from perfectly healthy natural fruit in the Southern States and our buds are taken from none but trees of first quality.

\section{FIRST IRIPENANG.}

The first in ripening about the first of August, in this latitude is

Hale's Early, a new rariety, equal in quality to Honest John; higher color, and on trees of equal age, ripens so as to fully mature before any succeeding variety. White flesh. In consequence of its tendency to rot about its season of maturity, it is worthless for market in most sections.

\section{SECONT RIPENING.}

Troth's Early Red, a small old rariety, a great bearer, ships well, and very popular South. White flesh.

\section{TIIIIRT RIPENING.}

Honest John, or Extra Early York, a seedling from Early York, which it much resembles, but it is larger and the fruit does not grow so tapering in size; leaves serrated with globus glands; the most popular Peach of its season in the New York market. White flesh.

IMountain Rose, white flesh. Ripens same time as the former. First quality, hangs on until well colored, and will entirely superceed the former as soon as known among orchardists.

\section{FOERE'TE REPENING.}

Crawford's Farly, originated in this county. A fine, yellow-fleshed market fruit, very popular South and East; not much set in this section, but is superceded by

Hance's Golden Rareripe, also a yellow Peach, being more round than the former; an abundant and regular bearer.

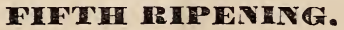

Old Mixon Free, a large, first-class Peach. In every respect bears transportation well. Popular in all sections. White flesh.

\section{SEX'TH TRERENTE.}

Stump the World. Tree very hardy; a good grower; regular and abundant bearer, fruit large, with a blush cheek; red at the stone, and bears handling well. Flesh white, rich and luscious. A decided acquisition.

Crawford's Late. Tree a rapid, erect grower, and regular bearer. Fruit very large, with yellow flesh, and too well-known to need further description.

Beers' Late. A seedling from Crawford's Late; and the fruit possesses all the leading characteristics of the parent, but the tree is more hardy and prolific.

IMary's Choice. A fine yellow Peach, an abundant bearer, and growing in favor. 
SEVENTH IRIPEVING.

Crockett. Fruit medium to large size; skin and flesh white, and free of red or pink at the stone. Much esteemed for preserving. Tree a good grower and abundant bearer.

Beers' Smock. A seedling of the Smock Free, similar in character, but larger, and the tree more vigorous.

Keyport White. A new Peach, pure white; considered the best known productive variety for preserving.

\section{EIGH'EII TRERATMG.}

Heath Cling. A large, white cling-stone, abounding in rich, sweef, vinous juice. Very popular South.

Salway. Represented as very late and promising.

We have a large number of other varieties of more or less merit, that we try as they appear.

\section{ORNAMENTAL VARIETIES.}

Van Buren's Golden Dwarf. A beautiful Dwarf variety. Fruit abore medium size. The leaves are rery closely set, of a deep green color.

Italian Dwarf. More dwarf than the former.

Blood Leaved Peach. This has leares as dark as the Blood Leared Beech, and having as well excellent fruit.

\section{APRICOTS.}

Breda, Moorpark, Early, Large, and Peach. 25 to 50 cents each.

\section{PLUMS.}

NAMIE.

EARLY.

COLOR.

Bolmars Washington,

Imperial Gag,

Lawrence's Farorite,

Smith's Orleans,

Yellow.

Yellowish Red.

" Green.

Reddish Purple.

Wild Goose, Yellow.-Large, beautifully mottled, sugary and melting* Tree vigorous and hardy, bears early and large crops, nearly proof against the curculio; bears transportation well, A very profitable market Plum. July.

\section{MEDIUM.}

Bleeker's Gage,

General Hand,

German Prune,

Green Gage,

Jefferson,
Light Yellow.

Yellow.

Blue.

Green.

Dark Yellow. 
Lombard,

McLaughing,

Martin's Seedling,

Purple Gage,

Columbia,

Coe's Golden Drop,

" Purple

Monroe Gage,

LATE.

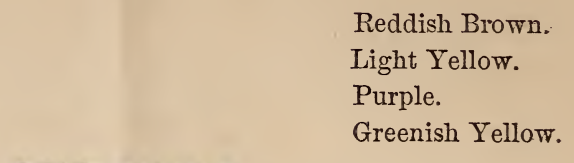

CHERRIES.

30 to 50 cents each.

NAME.

Black Tartarian.

Biggareau Rockport, "Cleveland,

Coes Transparent,

Early Richmond,

Knight's Early Blackheart.

May Duck,

Prussian Black Heart.

EARLY.

COLnR.

Pale Amber.

Yellowish Red.

Mottled Amber.

Red.

Red.

MEDIUM.

Amber Heart.

Black Eagle.

" Heart.

Belle de Choisey,

Biggarean Great,

" Late,

Elton,

Osceola,

Yellow Spanish.

LATE.

Carnation,

Downers Late Red,

Elkhorn,

Governor Wood,

Biggareau Napolean,

Prince Hortense,

Mottled Red and Amber.

Dark Red.

Yellowish Red.

Yellow and Red.

Dark Red, nearly Black.

Some of the varieties can be furnished on Mahaleb stocks, branched. low for Dwarfing.

\section{QUINCES.}

Apple, and Pear, 25 to 50 cents each.
Nottled Yellowish White.

Light Red and Amber.

Glossy Black.

Light Yellow and Red.

Yellow and Amber.

Bright Red. 


\section{CURRANTS.}

\section{Black Naples, \\ Cherry, \\ La Versailles,}

\section{NAME.}

Allen's Hybrid,

Adirondac,

Catawba,

Clinton,

Concord,

Creveling,

Delaware,

Diana,

Eumelan,

Hartford Prolific,

Isabella,

Iona,

Israella,

Maxatawny,

Walter,

\section{Missouri, \\ Victoria, \\ White Grape,}

\section{CRAPES.}

25 to 50 cents each.

COLOR.

White,

Black,

Pale Red,

Black,

Black,

Black,

Flesh Colored,

Pale Lilac,

Black,

Black,

Black,

Fine Red,

Black,

Yellowish White,

Dark Amber,
White Dutch.

\section{SRALL FRUTS.}

It is a fixed fact that the diversity and adaptability of the soil of the State of New Jersey and its geographical position between the two best markets in the United States, it is destined to surpass its sister States of the same latitucle in this very important branch of fruit culture, as well as other perishable market crops, which, of course, makes us feel quite independent as to the taunts of our neighbors excluding us from the Union.

By growing an equal proportion-beginning with Strawberries, then Raspberries, and finishing with Blackberries-it requires but one-third as many crates and baskets in proportion to the amount of fruit, as though only one of these rarieties had occupied the whole ground; it also gives a longer season of employment to the pickers, which, of course, is an inducement for them to seek the employment of those who keep fruit in rotation through the whole season.

\section{COOSEBERRIES.}

Houghton's Seedling, and other varieties, 15 to 20 cents each.

\section{BLACKBERRIES.}

$\% 5$ cents per dozen.

Blackberries are keeping pace, in commercial value and excellence with other fruits. This remarkably healthy fruit is now produced in sufficient quantities to no doubt produce a salutary effect upon the health of our large cities.

PROPAGATION.-Plants for new plantations should be raised from 
stools not intended for fruiting, as every plant properly taken up severs a feeding root, consequently the result will be very unsatisfactory to those attempting to raise plants and fruit on the same ground.

This precaution also applies to the Raspberry.

\section{VARIETIES}

Dorchester. Large, oblong, sweet, and of a peculiar flavor; much appreciated by some; possessing, in a slight degree, the flavor of the Mulberry.

Kittatinny. Canes very hardy. The best for general culture.

Lawton. The pioneer of improved high-bush Blackberry.

Wilson's Early. Fruit large, of first quality; supposed to be a hybrid between the high and low bush, but after the first year's growth the canes partake strongly of the high-bush, consequently there is sufficient strength to the canes to bear their fruit erect.

\section{RASPBERRIES.}

After a series of unsuccessful attempts to produce satisfactory results with tender Raspberries, we have come to the conclusion that to raise Raspberries so as to be within reach of the masses, we must discard the tender varieties, and confine ourselves to the recently improved hardy sorts.

Hardy Raspberries are of easy culture, adapted to any soil suitable for growing corn. The rows should be seren feet apart and the plants three feet apart in the row; any root crop may be raised between the rows the first season, after which they will require the whole ground. Be careful not to till too deep near the plants, as the feeding roots run near the surface. we have found an application of fine bone, to be worked in at the first tending in the Spring, to give very satisfactory results. The latter part of Winter, cut out the old wood that has born the year before, also be careful to cut back say one-third of the previous year's growth, which will reduce the amount of fruit to about what the plants will be able to bear, and so balance the bush that it will not require any stakes, as is the case with the tender varieties whose canes have been weakened by bending down for Winter protection.

PROPAGATION.-See the last paragraph on Blackberries.

VARIETIES.

Improved Black Cap. One of the best black caps for market, and much esteemed by those who like the native flavor of the Raspberry.

Philadelphia. Fruit rich and juicy, of purplish red color.

Large Miami. Black, very fine, ripening about the time of Philadelphia.

Herstine. Red, said to be superior to all others, and bears transportation well. 


\section{STRAWBERRIES.}

SOIL AND PREPARATION OF THE SAME.-The most produc tive soil for the Strawberry is a good sand and clay loam, but as this soil requires more culture than sandy soils, the latter are much used in some sections; they also have a further advantage in ripening the same variety of fruit earlier, and when heavily manured gire good returns.

As the crop is much shortened by dry weather, all stiff clay subsoils should be mellowed several inches below the depth of ordinary plowing.

As subsoiling heavy ground is essential for the largest yield, it also requires Winter mulching to keep the plants from being disturbed by frequent thawing. Cornstalks, one layer deep, has proved the best mulch for us; straw, salt hay, old seaweed, etc., (being careful to keep clear of any thing containing grass or weed seed), not more than one inch deep

TIME TO SET, CULTIVATION, \&c.-In some special cases it may be expedient to set from the middle of August to the middle of September, but undoubtedly the best time is in the Spring. Guard against setting when the ground is very dry, or on a windy day.

When plants are receired examine them at once; if they are heating, take them out of the package and keep them moist by trenching or otherwise until you are ready to set them; if any are quite dry, trench them in moist soil, covering tops and all (in most cases ordinary garden soil is too dry, and as fast as the plants are trenched it should be liberally wet); gradually uncorer the tops after three or four days, when they can be kept until the ground is ready.

As a field crop, set the plants in rows four to fire feet apart, and one foot apart in the row. Prepare the drills as for planting turnips several days previous; rake them down to the ordinary level no faster than wanted, which will furnish moist earth to set the plant in, which should have the earth compressed around it, so that the plant can not be drawn up again by one leaf without breaking it. Keep the ground clear of weeds and use the cultivator frequently; the second season, if the plants have made a good growth, little can be done except to cut out the coarse weeds with a knife; the third season, in most cases, will be the last crop of fruit which matures so early, the ground can be prepared for late vegetables or Winter grain.

GARDEN CULTURE.-Set in hills fifteen inches each way, cut all runners as fast as they appear; keep well mulched Summer and Winter, removing it to kill weeds and replace again; use fertilizers freely and they will gire surprising results. This kind of a bed may be kept four to five years, not longer. Or set in rows one by two feet; let them corer the ground at once and destroy the bed the next season after fruiting; to keep an annual supply set a fresh bed every season. This plan is more economical than the former, and gives better results with some rarieties. 
MANURES.-All the rarious composts of the farm should be old and well rotted, as coarse manures tend to rines more than fruit.

As it is requisite to get as good a growth as possible the first season, we should put in the drills before setting some good old compost or other fertillizer. An application of wood ashes on the surface, either before or after setting, is very beneficial ṇ most soils. Any compost of the farm, spread on in the Fall, will answer for a mulch at the same time.

We have taken great care in the growth of plants and Winter protection, and they will transplant readily.

\section{VARIETIES.}

Agriculturist. "(H.) Strong growing vines, very prolific. Fruit large and fine.

Burrs New Pine. (H.) Plants hardy and productive. Fruit pale red. Fine aromatic flavor; fine for table use, but too soft for transportation.

Charles Downing. (H.) Fruit medium to large, conical, deep scarlet. Fine flavor, productive, and promises well for market.

French's Early. (H.) One of the largest early berries. Rich and luscious. First quality for amatures.

Jacunda. (H.) Of the largest size. Appears well in market; stands transportation well; undoubtedly a fine variety for amatures, and profitable on heary soils, with special culture.

Kentucky: (H.) The latest variety. A seedling from Downers Prolific.

Iennings White. (H.) Fine for amatures; not excelled in flaror. Generally a shy bearer.

Lady Finger. (H.) A first-rate variety. Very distinct.

New Jersey Scarlet. (H.) Promises well. Firm flesh and handles finely. Excellent quality.

Triomphe de Gand. (H.) Excellent flavor. Much esteemed by amatures. Should be grown in hills.

\begin{tabular}{l|l} 
Black Defiance. (H.) & McAvoy Superior. (P.) \\
Barns Mammoth. (H.) & IVichigan Seedling. (H.) \\
Charltons Prolific. & President Wilder. (H.) \\
Hoveys Seedling. (P.) & Seth Boyden. (H.) \\
Longworths Prolific. (H.) &
\end{tabular}

\section{MISCELLANEOUS FRUITS.}

\begin{tabular}{|c|c|}
\hline $\begin{array}{l}\text { Barberries, } \\
\text { Butter Nut, } \\
\text { Filberts. }\end{array}$ & $\begin{array}{l}\text { Hardy Almonds, } \\
\text { Hop Tree. } \\
\text { Madeira Nut, }\end{array}$ \\
\hline
\end{tabular}

Mulberry. Black. New American.

" " Downings.

"White.

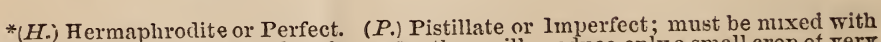
those marked $(H$,$) say every fourth row, \%or they will produce only a small crop of very$ imperfect fruit. 


\section{ESCULENT ROOTS AND VEGETABLE PLANTS}

For the garden, in their season; including

Rhubarb, Linnæus, Giant, and Victoria.

Asparagus. One and two year plants of the old rariety.

"

Conorer's Colossal, of fine large growth, not believed to be attainable before this variety was introduced by Van Sicklen.

\section{Coniferae. Evergreens.}

Our customers will please bear in mind that most of the new and rare evergreens are necessarily small. We can furnish extra-sized specimens of a few rarieties at increased rates. We also have a number of beautiful novelties in the course of propagation, which will shortly be ready for distribution, not enumerated in this edition.

Prices for shipping sizes, 50 cents to $\$ 1.50$ each; except when noted.

ABIES. SPRUCE.

A. alba. Whrte Sprice. Very compact and regular in growtl, and highly ornamental.

A. ezcelsa. Nonwar Sprece. Unirersally admired, and more extensively planted in this country than any other erergreen. It is beautiful at any size, from the smallest plant to the full-grown tree. Easily transplanted and a fast grower. It forms an excellent and highly ornamental barrier against high winds for farm crops or buildings. It also can be clipped to form low hedges.

"Where towering firs in conic forms arise,

And with a pointed spear diride the skies."

A. nigra. Black Sprece. A native tree, growing to the height of 5 feet. Dense, dark green color; well adapted for cold situations; rery pretty while young.

\section{ABIES TSUGA. HEMLOCK.}

A. Canadensis. Hemlock Spruce. One of the most abundant of our Northern trees; and whether seen on its native mountains, where the forests of it are so dense as almost to exclude the light of day, or standing alone on a lawn, it yields to none in grandeur or graceful beauty. It also makes a rery pretty hedge. Dense habit, with drooping branches. Hardy.

ABIES PICDA. Fir.

A. balsamea. BALSAM Fir. A very popular evergreen, and while young its remarkably symmetrical form and rich foliage render it an attractive tree. Hardy, and of rapid growth. 
A. Nordmanniana. Norduraxn's Fir. One of, if not the best evergreen trees, having more good qualities than any other variety. Rapid growth, symmetrical form, and dark green color ; $\$ 1.50$.

A. pectinata. Europear Silver Fir. A tree of ancient renown, ranking with the Cedar of Lebanon. According to Virgil, it was of Silver Fir the Roman javelins were made. When once established a free grower and very beautiful. This tree is not appreciated as it should be.

A Pinsapo. Pinsapo Fir. Brought from " amidst the hills of Spain." Deep green leaves, singularly pointed all around the shoots; compact habit,. elegant, $\$ 1.00$

\section{BIOTA. Eastern Arbor Vitæ.}

B. orientalis. ChINese ARBor Virze. A small tree, with the branches: growing almost perpendicular; light green color.

var. aurea. Golden Arbor Vite. A Chinese variety, with leaves of a golden yellow appearance; is now getting pretty well-known, and popular; compact habit.

\section{CUPRESSUS. CYPRESS.}

C. Lawsoniana. Lawson's Cypress. Grows to the height of 100 feet. Exceedingly beautiful; the feathery, drooping branches, swaying with a gentle breeze, resemble green piumes ; $\$ 1.00$.

C. Nutkænsis. NoоTkA Sound CrPREss. Tall growth, with dark green foliage. Quite desirable; hardy ; $\$ 1.50$.

JUNIPERUS. JUNIPER.

J. communis. Common JunIPER. A native tree growing frome 6 to: 10 feet; with proper pruning it presents a beautiful appearance.

var. Hibernica. IrIsH JUNIPER. Considered the most desirable of its class. Upright, dense and rapid grower, forming a green column. Much used in cemeteries.

var. Suecica. Swedish Juniper. A small pyramidal tree, with yellowish green foliage; very ornamental and hardy. Succeeds much better than Irish Juniper in some situations.

J. prostrata. Prostrate Juniper. A native trailing variety forming wide circles. Rapid grower, dark color, and very hardy. Beautiful for rock-work.

\section{IIBOCEDRUS. INCENSE CEDAR.}

L. dezurrens. Yellow Cedar. From the Pacific coast, where the giant trees abound; forms a majestic arbor 100 feet in height. 
PINUS. PLNE.

P. Austriaca. Black Austriax Pine. A very strong growing, handsome tree, from Austria, perfectly hardy, and becoming a general favorite. Long, stiff, dark green leaves. One of the best evergreens for wind brakes.

P. cembra. Swiss Stone Pine. Native of Siberia, Switzerland, etc. One of the rarer kinds, bearing an edible fruit. Tall and upright, and considered by some the handsomest of the whole genus. Pretty form, medium height, compact, light green color; rather slow growth ; $\$ 1.50$.

P. excelsa. Bнотал Prne. From the Himalaya Mountains. The long drooping foliage and luxuriant growth of this tree entitle it to be styled the queen of its tribe. Perfectly hardy. Leaves long, slender, and glaucous green. Perfectly beautiful in a favorable situation.

P. Iaricio. Corsican Pine. A beautiful tree from the South of Europe, with long, wary, bright green leaves. Fast grower.

P. strobus. White Pixe. Very generally known outside of the pitch pine district; much esteemed; perfrctly hardy.

P. sylvestris. Scotch PrNe. Decidedly the best pine for planting near the sea shore, being very hardy and a rapid grower, with short, light green leares. Valuable for screens. From the highlands of Scotland.

\section{RETINISPORA. JAPAN CYPRESS.}

This new genus of trees are from Japan, and strictly speaking are not distinct from the true Cypress, but they are exceedingly beautiful and worthy of cultivation, being also quite hardy.

R. obtusa. Obtuse-leaved Retinispora. Of tall and upright growth. Graceful, drooping branches, with glossy green leaves marked beneath with silvery white bands.

R. plumosa. Plume-like Retinispora. A rery rare, pretty variety, with short, slender branches covered with small, bright green leares.

R. squarrosa. Squarrosi-leaved Retinispora. Exceedingly handsome variety, with light bluish-green foliage, and slender branches.

\section{SEQUOIA. MAMMOTH TreEs.}

S. gigantea. Great Trbe of CAliforrla. (Washingtonia.) This vegetable giant is from the Sierra Nevada Mountains of California, and often attains the height of 200 to 300 feet, with a trunk from 75 to 90 feet in circumference. A rapid grower, succeeding in favorable situations ; $\$ 2.0 \mathrm{C}$

TAXUS. YEW.

T. baccata. ExGLish Yew. This is one of the most noted trees of Old England. Dark and solemn in its aspect, it has been deemed peculiarly appropriate to griveyards and cemeteries. Loudon says of the one 
in Frontingal Churchyard in Berkshire: "This venerable yew, which in all probability was a flourishing tree at the commencement of the Christian era, mry yet survive for centuries to come." It is better for being somewhat sheltered in a cold climate.

T. erecta. ERECT Yew. A variety of the English Yew, but of more upright growth, with slender branches,, densely corered with small, dark green foliage. Pyramidal form, hardy and cesirable.

T. fastigiata. InISH Ynw. This is a variety of the above, growing much more upright, and is a striking and ornamental plant, forming a regular column of thick, dark green foliage. Also very pretty as a monumental tree. It should be planted in a sheltered situation.

THUIOPSIS. JAPAN ARBor Vite.

T. dolabrata. AXE-LEAVEd ARBor Vite. Remarkably nice, dark green foliage, glaucous underneath; conical form, with spreading branches, drooping at the extremities; beautiful.

\section{THUJA. Western Arbor Vita.}

T. occidentalis. American Arbor Vita. Well knotrn for its beautiful foliage, and peculiarly bright, pleasing, general appearance. One of the best plants for ornamental hedges and screens, being a vigorous grower and bears pruning well.

var. aurea. Golden ArBor Vitæ. A very dwarf, compact, pretty variety, with the ends of the foliage tipped with golden yellow.

var. compacta. Panson's Arbor Vite. A fine variety, of a dwarf, compact habit, with conical heads of yellowish green foliage. Perfectly hardy.

vax. globosa. Globe-Headed ARBor Vite. A variety ornginated near Philadelphia, where it is very popular. Forms a dense, dwarf, globular, and very pretty tree.

var. Floveyi. Hover's Goldex ARBor Vitze. A charming variety with foliage of a bright, yellowish green hue; compact and globular in form.

var. pumila. Воотн's DWARF ARbor Vitæ. Dark green foliage; dwarf, dense, rounded in form; one of the best.

var. pyramidalis. UpRIGHT ArBor Vitæ. Compact, with dark green foliage, and exceedingly erect form. Very conspicuous and desirable.

var. Reedii. ReED's Areor Vitze. A good rariety valued for its slender twigs and bright green color. Will become popular, as it becomes known. 
var. Siberica. Siberlax Arbor Vite. Perhaps the finest of this family, being perfectly hardy, and maintaining its true color better than any other through the Winter. Well adapted for single specimens on lawns, being very neat and compact, oftimes appearing as though it had been xeatly clipped; fine for hedges.

var. "Tom Thumb." Ellwaxger \& BArRy's Heath-Leated. A neat, ornamental variety, of rounded form, with slender shoots. Being extremely dwarf, makes it desirable for gardens, lawns or cemeteries, where large trees may not be admitted.

\section{Deciduous Ormamental Trees.}

Price, 50 cents to $\$ 1.50$ each, ascording to size; except when noted.

ACER. MAPIE.

A. campestre. Exglish, or Cork-b.rifed Maple. A dwarfish growing tree, with small glossy, lobed leaves and rough bark. Fine for lawns.

A. colchicum rubrum. Red Colchicur Maple. From Japan; medium size. The young foliage deep purplish red. Hardy.

A. dasycarpum. Silver-Leaved Maple. More generally planted on the street and for shade than any other tree in this country. Its very rapid growth and fine appearance accounts for its extraordinary popularity. Many of our customers have the erroneous impression that this tree is the Silver Abele or Poplar. (Populus Alba.)

A. negundo. Ash-Leaved Maple. A distinct, free growing variety.

A platanoides. Norwar Maple. A handsome tree of the first rank; a fast grower, with glossy, brilliant, green foliage; compact in form. Free from insects and disease.

A. pseudo platanus. Srcayore Maple. One of the most beautiful of shade trees, with large, dark green leares and a fine spreading top; grows fast, retains its leares late in the Autumn, and changes in rich colors.

A. rubrum. Red, Soft, or Swayr MAAPLE. A rapid grower, remarkable for its crimson foliage in the Autumn; being of indescriable gorgeous tints. Flowers early in Spring.

A. saccharinum. Scgar Maple. A native of our forest, where it furnishes an excellent sugar in large quantities. As a shade tree, and in the brilliancy of its Autumnal tints, it scarcely has a superior from any part of the world. Straight trunk. 


\section{死SCUlus. Horse Chestate.}

E. glabra. OHIо Brckeye. From the Western States, forming large tree. Its beautiful small flowers, are of pale yellowish hue.

Æ. Hippocastanum. Common Honse Chestnut. Prized for its dense, luxuriant foliage and splendid flowers, white spotted with purple and yellow. Tree of pretty form and large size.

var. rubicunda. Red Flowering Horse Chestret. One of the most beautiful ornamental trees, bearing fine, distinct rose colored flowers.

aillanthus. Chinese Christiax Tree.

A. glandulosa. Comor Ailaxthus. Not popular, but desirable for planting in some localities where other rarieties will not succeed.

\section{ALNUS. ALDER.}

A. glutinosa. European, or Commox Alder. In good soil or moist situations, an exceedingly rapid growing tree, eren surpassing t'..e SILrER MAPLE. The trunk is straight, branches regularly disposed, leares of a brilliant green color, remaining on the tree and retaining their color, rery late in Autumn. In beauty of form and picturesque appearance, this tree is unrivaled in river scenery.

BETUIA. BIRCH.

B. alba. White Brich. The white, papery bark, and delicate pendulous branches, justifies Coleridge in calling it-

"Most beautiful

Of forest trees-the lady of the woods."

Nothing can be more light and airy than its slender drooping spray, circling, like a fountain-shower, those who sit beneath its branches-

var. pendula laciniata. Weeping Cet-leated Birch. In addition to its graceful drooping branches and the silrery whiteness of its bark, the deeply cut fern like leares are also exceedingly striking.

var. populifolia. Poplar-leaved Birch. A small sized natite tree, of graceful growth, and large tremulous foliage.

B. lenta. Stweet Birch. A native tree of large growth, wiih shiny green leares and dark brown bark of a sweet, aromatic taste.

BRoussonetia. Mulberry.

B. papyrifera. PAPER Mulberry. Of rapid growth, dense foliage, spreading habit; rery ornamental, and one of the hardiest for the sea-coast.

castanea. Chestivet.

C. vesca. Europeax or Spanish Chestrut. Although greatly prized for its fine, large edible nuts, yet on a large lawn it produces a beautiful effect as an ornamental tree. 
var. Americana. Americax Chestrut. Fruit not as large as the former, but better flavored; tree of larger growth; fine for street planting in South Jersey.

\section{CATALPA.}

C. Keompferii. Keomprer's Calalpa. Remarkable bushy and dense habit. Should be grown in bush form.

C. syringæfolia. Stringa-leaved Catalpa. A noble flowering tree of large leaves and white flowers tinted with red and violet. Blooms in July and August.

\section{Cercis. Red Bud. Jldas Tree.}

C. Canadensis. Americax Judas Tree. A native tree, from Canada, with heart-shaped leares and clusters of pretty reddish-purple flowers, appearing before the foliage in early Spring.

CLADRAstis. Yellow Wood.

C. Tinctora. Virgitil LeteA. A fine dwarf native tree, with long, graceful racemes of white pea-shaped flowers at the end of the branches.

\section{CYTISSUS. Goldex Chan.}

C. Laburnum. Goynox Labernos. A beautiful ornamental tree, bearing drooping racemes of yellow flowers in profusion

Through the Laburnum's drooping good

Rose the light shaft of Orient mould.-Hemans' Palm Tree.]

FAGUS. BEECH.

F. ferruginea. Ayericax BeEch. A large tree, with smooth bar $\mathrm{k}$ spreading branches, and profusion of pretty toothed leaves.

F. sylvatica. Europeax BeEch. A large tree of lofty and compact habit, with large foliage.

var. cuprea. Copper-Colored BeEcr. A fine tree, with reddish purple foliage; being somewhat lighter than the Purple-leared Beech; $\$ 1.50$.

var. laciniata. Cut-Leaved Beech. Beautiful erect, free growing tree, with handsome cut leares; very distinct and striking; \$1.50.

var. pendula. Weeping BeEch. A medium sized tree, of decided weeping habit; graceful and elegant; $\$ 1.50$.

var. purpurea. PrRple-Leaved Beecr. Fr.s.ge of a deep purple color, making a highly ornamental tree of symmetrical form; very conspicuous and attractire on the lawn! $\$ 1.50$. 


\section{FRAKINUS. AsH.}

F. Americana. Auerican White Ash. Tall and rapid growth, with pretty pinnate light green leaves, bearing large clusters of small creamy-white seed ressels in the Autumn.

var. aucubæfolia. AtcubA-LEAvEd Ash. Valued for its spotted foliage, as it resembles the Gold-dust shrub.

F. excelsior. Europear AsH. Well worthy of cultivation as a shade and ornamental tree. A fine grower, with thick and handsome foliage.

var. angustifolia. WILlow-LEAved Ash. A rapid, robust grower, with narrow, wary leares, and light spotted bark.

var. atrovirens. DWARF, CRISPED-LeAved Asr. Foliage dark green and curiously crisped. Striking and beautiful.

var. aurea. GOLDEN-BARkED Ash. A striking and distinct tree, of irregular habit.

var. monophylla. Snjgle-leaved Ash. A rapid, robust grower, with single broad leares; unlike most varieties whose leares are pinnate.

var. pendula. WeEping Asm. One of the finest for the lawn, being of rapid growth, spreading and very weeping habit.

F. juglandifolia. Black, SWAMP, or WALxut AsH. A majestic tree; fiue for river scenery.

F. ornus. Etropeax Flowerntg Ash. A very ornamental dwarf growing tree, with greenish white fringe-like flowers, in large clusters.

For Mountair Ash, see Pyrus Sorbus.

\section{GLEDITSCHIA. LOCUST.}

G. triacanthos. Hoxey LocusT. A rapid growing, graceful tree, with long thorns, and beautiful delicate foliage; much used and very desirable for hedges. When grown singly, very conspicuous and beautiful.

\section{GLYPtOSTROBUS. EMbossed Crpress.}

G. pendulus. Weeping Deciduous Crpress. A small upright, conical shaped tree, with drooping branches and rery graceful, deiicate foliage.

GYMNOCIADUS. KeNTUCKY CoFfEe.

7. Canadensis. A natire, odd growing tree, with pretty, Locustlike foliage. The seed or bean is sometimes used as a substitute for coffee.

\section{JUGLANS. WALNUT.}

J. cinerea. Butternut. A fine, strong, ornamental tree, much valued for its well known fruit. 
J. nigra. BLACK WALxuT. A very ornamental tree of spreading habit, with round head; desirable for its fruit.

J. regia. Englisir Walnut. A dwarf tree, similar to the preceding, with larger and sweeter fruit.

\section{KOLREUTERIA.}

K. paniculata. Paxicled-flowering Kolreuteria, A beautifui, small tree, with a loose head, and covered with yellow flowers in July and August, followerl by large bladder-like capsules.

LARIX. LARCH.

L. Europea. Europeax Larch. A very lofty growing ornamental tree of vigorous habit, with slender, drooping branches, covered with fine yellowish green foliage; conical and symmetrical form.

\section{IIGUIDAIMBER. SWEET GUM.}

L. styraciflua. A pretty, round headed tree, with rough, corky bark, and deeply lobed, star-shaped, glossy green leaves, changing red in the Autumn; exceedingly ornamental.

\section{IIRIODENDRON. TULIP TREE.}

L. tnlipifera. (Erroneously Yellow Poplar.) A majestic, rapid growing tree, with peculiar shaped large foliage, and magnificent tulip-like flowers.

\section{MACLURA.}

M. aurantiaca. Osage ORAxge. When grown to a tree very ornamental, with large corky fruit a yellow color; quite pretty, but mostly used for hedges. (See hedge plants.)

\section{IMAGNOLIA.}

It would be difficult to say too much in faror of this class of trees, after considering their rapld growth, magnificent foliage, elegant flowers, regularity of form, and freedom from disease and insects. Prices, old varieties 75 cents to $\$ 1.50$ each. New varieties $\& 1.50$ to $\$ 3.0 q 0$.

\section{American Sipecies.}

M. acuminata. Cucumber Tree. A majestic growing tree 70 to 80 feet high, with large conspicuous leaves 6 to 10 inches long, and greenish, yellow bell-shaped flowers.

IM. macrophylla. Gireat-Leaved Mignolia. Medium sized, with leaves two feet in length, and dull white, very fragrant flowers nearly 12 inches in diameter. Rare; $\$ 2.00$ to $\$ 3.00$.

IM. umbrella. Umbrella Tree. (tripetela.) Small sized tree of rapid growth, with enormous light green leares, and large creamy-white flowers. 


\section{Asiatic Species.}

M. conspicua. Yulan Magrolia. Has beautiful white flowers, which appear before the leaves; very fragrant and showy; $\$ 1.50$.

M. obovata. PurPle-flowerivg Magrolia. (purpurea.) Small growth, with pale green leaves and cup-shaped flowers, dark purple without and white within.

M. Soulangeana. Soulatge's Magrolia. A hybrid resembling M. Alexandrina, of small and slow growth, with large, beautiful purple and white flowers, which appear before the leaves; $\$ 1.50$.

\section{MORUS. MULbeRry.}

M. alba. White MulberRr. A variety from China, of rapid growth and slender twigs; white fruit.

var. multicaulis. Downing's Everbearixg Mulberry. A strong growing variety, with broad glossy leaves; very ornamental, and bearing large, black fruit, for which it is prized.

\section{NYSSA. TUPELO}

N. multifora. Sour Gur. Medium sized tree, with horizontal branches. Foliage deep green, changing to brilliant crimson in Autumn.

\section{PAULOWNIA.}

P. imperialis. A magnificent rapid growing tree, very large leares and showy flowers. Rapid growth.

\section{PERSICA. PEACH.}

P. rubrum. Blood-Leavfd Peach. A new, very ornamental tree; with dark purple leaves, and splendidifruit, uniting the beautiful and useful more than any tree we are acquainted with.

\section{PLATANUS OCCIDENTAIIS. BUTTON-WOOD.}

A lofty growing tree, producing rough balls, from which it is named, It is sometimes called Srcavore. A native tree.

\section{POPUIUS. POPLAR.}

The Poplars are very lofty, rapid growing trees, and thrive in almost every soil and situation. Their conspicuous foliage make them striking and desirable.

P. alba. Silver-Leaved Abele. Admired for the silrery whiteness of the unclerside of the leaves, and the beautiful green of the upper surface; said to abound on the banks of the Euphrates, near the site of ancient Ninevah. Most hardy for ocean exposure.

P. angulata. CARounA, or Cotrox Tree. Very large leares and brittle branches. 
P. balsamifera. BAlsoy, or B.twy of Gile.tD. A rapid grower, with large luxuriant foliage.

P. candicans. Oxtario Poplar. Broad, grayish green leares.

P. dilatata. LoMBardy Porlar. Vigorous grower and of remarkable upright habit. Exceedingly conspicuous, and creating marked effects in large groups.

P. grandidentata pendula. Weepixg LARge-toothed Aspex. Decided weeping habit, and quite attractive.

P. monilifera. Blick Italiax, or Cotron Wood. Dark green glossy foliage, with clark branches, when young.

P. tremula. Aspex-Leared Poplar. This beautiful tree is well known for its trembling foliage, which moves with the slightest impulse of the air. Its leares are roundish, smooth, and stand on long, slender footstalks.

PTELIA. HoP TREe.

P. trifolia. The blossoms of this tree are used for the same purposes as the ordinary Hop.

PYRUS MALUS. APPLE.

P. prunifolia. Stberiax Crae Apple. Assorted; all with ornamental flowers and fruit. The fruit is highly prized by some for preserring.

PYRUS SORBUS. MotxtAN Ash.

P. Americana. Ajericar MIt. AsH. Similar to European, but stouter grower, and more spreading, with white flowers followed by clusters of scarlet berries during Autumn and Winter.

P. aucuparia. Eunopenx MT. Asr. A fine shaped hardy tree cor ered with large clusters of scarlet berries.

var. pendula. Weeping Mrt. Ash. Very beautiful in its foliage and clusters of flowers and berries. Very weeping habit; $\$ 1.00$

var. quercifolia. OAK-LEAVED MT. Ash. Deeply toothed, downwhite foliage, making it attractive; $\$ 1.00$.

\section{QUERCUS. OAK,}

Q. cerris. Tunker OAk. A pretty, round headed tree, of quicker growth than the English, and deeper cut foliage; quite distinct and hardy.

Q. pedunculata. Coмmox British OAk. Oblong, smooth, lobed obtuse leares; stalks of the fruit elongated. Tree from 80 to 100 feet high, with spreading, tortuous branches and spray, and when standing singly, with a head often broader than it is high.

Q. pyramidalis. PrRamdil OAk. A rariety of the European erergreen oak, of upright growth; beautiful. 


\section{SALISbURIA. Maidex HaIr Tree.}

S. adiantifolia. JAPAN GINKGo. A beautiful, rare, dwarf tree, with pale green, fan-like foliage, of a thick, leathery nature; when pruned or cut back, it forms a beautiful, compact head. $\$ 1.00$ to $\$ 1.50$.

\section{SALIX. WILLOW.}

S. alba. White Willow. Very hardy; will grow rapidly in most any situation, even on quite sandy soils.

S. Americans pendula. New Americax Weeping Wrllow. Has long, slender, pendulous branches; can be trained to a pretty form; graceful and elegant. $\$ 1.00$ to $\$ 1.50$.

S. annularis. RING-Leaved WILlow. Peculiar curled leaves; pretty and distinct.

S. Babylonica. Common Weeprig WrLlow. Originally from Asia and grows to a large size; unsurpassed for river scenery or moist situations, for what can be more pleasant, on a hot Summer's day than to sit beneath the grateful shade-

\section{"Around the spring- \\ Where Weeping Willows wave."}

S. caprea pendula. Kilvariock Willow. Beautiful, pendulous branches, the best of all the Willows. We grow them in two forms, the pryamidal and the umbrella, both of which are exceedingly handsome. $\$ 1.00$ to $\$ 1.50$.

S. rosmarinifolia. RosMari-LEAved Willow. Handsome, with beautiful delicate foliage. In bush form 50 cents; standards $\$ 1.00$ to 1.50 .

S. purpurea. Ptrple, or American Fountain Willow. Narrow, grayish green leaves and purple branches.

\section{TAXODIUIM. DeCIDUous Crpiess.}

F. disticha. The ordinary roofing shingle is made from this tree. A very straight, symmetrical tree, with soft, feathery foliage, does welk in moist situations; perfectly hardy here, and grows to an enormous size South.

\section{TILIA. LINDEN.}

T. Americana. AMerican Linden, or BAsswood. A rapid grower, with large, heart-shaped leaves; good for the street or lawn.

F. Europæa. Eunopean Linden. A tree of ancient renown, and universally admired; a free grower, and makes a dense shade, rivaling the Horse-chestnut. It is from the bark of the Linden that the Russia mat, in such universal request for packing and tying, used by gardeners, and furniture packers, is made. 
var. alba. Silver-leaved, or Argentea Lindex. A beautiful new variety from Hungary, with foliage downy-white underneath, which it retains late in Autumn; rapid grower and symmetrical form.

var. alba pendula. WeEPLig Linden. Slender, drooping branches, and large, grayish green foliage; distinct, ornamental and conspicuous; $\$ 1.00$.

\title{
ULMUS. ELM.
}

U. Americana. White, or AMfricax Ely, One of our most noble native trees, of weeping habit; lives and thrives to a great age.

U. camprestris. ExGlisi ElM. A lofty tree, with upright branches, but not as good a grower as the last.

U. montana. Sсотсн, or WrCh ElM. Dark foliage, and vigorous grower.

var. Pendular. Canperdown Weeping Ely. Large, shiny leaves, and drooping branches; distinct and beautiful.

\section{Deciduous Flowerixg Shrubs.}

\author{
Prices 2 year plants, 30 cents each; $\$ 2.5 \mathrm{C}$ per 10

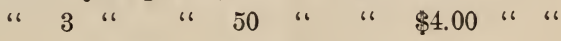 \\ (Except when noted.)
}

We have many varieties that are fine for low screens and ornamental hedging, at reduced rates in large quantities.

AMORPHA. INDIGO SHRTB.

A. fruticosa. Shrubby, producing long spikes of bluish flowers in July. Handsome.

\section{AMYGDALUS. ALMOND.}

A. rosea pumila fl. pl. Dwarf, with double, white flowers.

BERBERIS. BEREERRY.

B. purpurea. Purple-leaved Berberry. Showy flowers and rich dark purple leaves.

\section{CALIICARPA.}

C. purpurea. From Japan, and is loaded with brilliant violet berries in Autumn. 
CALYCANTHUS. AlLSPICE.

C. Floridus. Sweet Scented Shrcb. Double, purple, very fragrant flowers; 75 cts.

CATALPA. India Beax.

C. Bungii. Bunge's Catalipa. A dwarf tree, with fine large foliage; flowers in large clusters, 10 to 12 inches long; 50 cts.

ChIONANTHUS. White Frivg.

C. Virginica. Virginian White Fringe. A large shrub, with showy foliage, and delicately fringed with flowers.

Colutea. Bladder Senna.

O. arborescens. A tall shrub, with dull yellow, pea-like flowers in June, and bladder-shaped pods in August.

CORNUS. DOGWOOD.

C. sanguinea. RED-Twiged DnGwood. Purple fruit, and conspicuous branches in Autumn and Winter.

CORYLUS. HAZLE.

C. Avellana. Europear Hazel Not. Excellent fruit; fine for massing.

CRATEFGUS. THORX.

C. pyracantha alba. Pure white fruit; fine for hedging; $50 \mathrm{cts}$.

CYDONIA. QULTCE.

C. japonica. HARd JAPONICA, or Flowerng Qunce. Vivid scarlet flowers; very profuse; $50 \mathrm{cts}$.

var. fl. alba. White Flowernig JAPAx Quince. Delicate light flesh colored flowers; 75 cts.

\section{DEUTZIA.}

D. crenata fl. pl. Double-Flowerifg Deutzia. New and beautiful, with double white and rose tinted flowers; one of the best of hardy shrubs.

D. gracilis. Slender-growirg Deutzi. Beautiful, delicate, graceful, pure white flowers; very profuse. Excellent.

D. scabra. Rough-elaved Deutzia. Tall, with splendid, drooping white flowers.

\section{DIERVIIIA. WEIGELA.}

The Diervillas, like the Deutzias, are very handsome, and deserre a place in every collection. 
D. amabilis. Lovely Weigela. Beautiful pink flowers, which it produces the entire Summer.

var. alba. Lovely Wirite WeIgelA. A sprout of the preceeding with white flowers.

D. hortensis nivea. Silvery White Weigela. Strong grower and profuse bloomer; 75 cts.

D. rosea. Rose Colored Weigela. Fine foliage, and literally covred with clear pink, changing to flesh colored flowers.

eUONymus. Spindle Tree.

E. Europeus. Bunvirg Busir. Similar to American, but better in this locality.

FORSYTHIA. GOLDEN BELL.

F. Fortunii. Fortunes Forsytila. Handsome foliage, like the Maiden Hair Tree. 50 cents.

F. viridissima. Yellow flowers, appearing in early Spring, before the leaves.

\section{GENISTA.}

G. scoparia. Scotch, on Wirte Brooy. Long, slender, evergreen branches, with bright yellow flowers in bunches.

hIBISCUS. AltheA or Rose of Sharon.

The Altheas are very handsome, strong growing shrubs, with dis tinctly colored bloom, which appear profusely in August and September. Excellent for hedges, screens, and late blooming.

Hibiscus. A large collection, including the leading varieties.

\section{HYDRANGEA.}

F. arborescens. Wild HydraxgeA. Tall growth, white flowers and orate, green leaves.

H. hortensia. Garden Hrdrangea. A favorite, with rose colored flowers; nearly hardy.

H. paniculata grandiflora. New, from Japan, with large trusses of pure white flowers, remains in bloom a long time. Hardy; $\%$ cts.

H. quercifolia. OAK-Leaved Hydraxgea. Leares and shoots wooley, turning crimson in the Autumn; flowers white changing to purple; $50 \mathrm{cts}$.
F. Imperatrice.
F. nana.
H. Japonica rosea.
H. Rouei.

The last four are our importation of the Spring of $18 \pi 2$.

HYPERICUM. ST. JOHN'S WART.

H. calycinum. Large Flowerixg St. Johx's Wart. Beautiful yellow flowers and dark green foliage. 


\section{LIGUSTruim. Privet or Prim.}

I. sempervirens. Evergreer Privet. Small dark green leaves, which it retains until mid-winter.

\section{IONICERA. UPRIGHT HONEYSUCKLE.}

L. Tartarica. alba. White TARTARicA. Produc esdelicate white flowers in profusion.

var. rosea. Rose TARTARIA. Profuse.

var. rubra grandiflora. GREAT RED FlowERITG. One of the finest of this class; 75 cts.

PEgonia. Tree Peonia.

P. rosea. Rose-colored Peory. A beautiful plant, with very fragrant flowers.

$\$ 1.00$ to $\$ 3.00$ each; according to size.

Pavia. Dwarf Horse Chestrut.

P. macrostachya. DWarf White Horse Chestrut. A very ornamental spreading shrub, with spikes of white flowers.

\section{PHILADELPHUS. SYRIYGA.}

P. coronarius. Common Mock Oraxge. Yellowish white, very fragrant flowers.

P. Gordoniana. Gordor's:SyrINGA. White flowers.

F. grandiflora. Large white flowers.

\section{RHUS. SUAACH.}

R. cotinus. Syoke Tree or Purple Frixge. A gorgeous, distinct, large shrub, bearing curious panicals of brownish green, silk like flow. ers in great profusion in July. The flowers change to a purplish hue; should be in every collection.

\section{RIBES. CURRANTS.}

R. aurea. Missotri CotrRart. A vigorous grower, with delightfuI spicy fragrant yellow flowers.

SPIRAEA. MEADOW SWEET.

S. billardii. BILlARD's SPIR玉A. Fine bright rose flowers in spikes.

S. chamædrifolia. GERMANDER-LEAVEd SPIR玉. Small white flowers and scolloped leaves.

S. Douglassi. Dotglass' SPIREA. Conspicuous, deep ¿rose flowers in spikes.

S. opulifolia. Sxow-ball leaved SpIRæA. A strong grower, with large white flowers in panicles. 
S. prunifolia fl. pl. Plcme-teated Spirea. Small double white flowers, which appear before the leaves, and completely corer the stems; often called Bridal Wreath.

S. Reevesii or lanceolata. LANCE-LEAved SPIR.A.A. Large trusses of magnificent white flowers; profuse, one of the best.

var. fl. pl. Dodble-floweriyg Reetes Sirka. Very double charming white flowers in abundance.

salicifolia alba. Willow-Leated SPIReA. Spikes of white flowers and long narrow leares.

\section{STUARTIA.}

S. pentagyna. Malachodexdrox. Large cream colored flowers, showy; $\$ 1.00$.

SYMPHORICARPUS. ST. PETERs' Wort.

S. racemosus. Sxowbenrs. Conspicuous white berries; very pop ular.

S. vulgaris. Indiax Cernant. Bright red berries; profuse. Ex cellent.

\section{SYRINGA. LILAC.}

S. Josikea. Dark purple flowers resembling the white fringe.

S. Persica. Commox Persinar Linac. Purple, fragrant flowers.

S. virginalis alba. Pure white.

S. vulgaris. Commox Perple Lilac. Vigorous, and free bloomer.

\section{VIBURNUM. ARROW RoOT.}

v. Opulus. Sxow Ball, (Geelder Rose.) An old farorite, bearing pure white, wax-like balls, in clusters.

v. Oxycoccos. Craviberry Tree. Its large red acid fruit, renders it very ornamental in the early part of Winter. 


\section{Evergreen SHrubs.}

50 cts. each, except when noted.

AUCUBA.

A. Japonica. Goud Dust Tree. Laurel-like, dark green leaves, mottled with golden yellow spots; prefers a shady situation.

BOXUs. Box.

B. sempervirens. Tree Box. A robust grower, can be made to as. sume any form, if properly trimmed.

var. myrtifolia. MrrRTLE-LEAVED Box. Small obovate leaves. Bush, cone shaped.

\section{EUONYMUS. SPINdle Tree.}

E. Japonica. JaPAN Euonruds. Bright, deep green shiny foliage, not quite hardy.

var. argenteus. Silver Variegated Euonyrus. Shiny, green: foliage, margined with white.

var. aureaus. GoLden VARIEGATFD Euonyurus. Leaves spotted ands striped with yellow.

IIALIMIA. SheEP LAUREL.

I. latifolia. Calico Bush. Rich shiny foliage, and beautiful pink and white flowers; when old it becomes curiously gnarled and twisted.. 75 cts.

MAHONIA. ASHBERRY.

M. Japonica. JAPAN MAHONIA. Large leaves, and beautiful flowers, followed by clusters of dark purple fruit. $75 \mathrm{cts}$.

RHODODENDRON. ROSEBAY.

R. Catawbiense. Catawba Rosebay. Very desirable shrub with leathery, shiny green foliage, with magnificent clusters of large bell-shaped lilac-purple flowers, from June to August. Our collection embraces a large variety of sorts and colors. They prefer a shady situation and light soil, and need a slight protection in Winter; $\$ 2.00$.

R. maximum. Great Laurel. Clusters of fine, pale rose flowers: with spotted throats, and large thick leaves ; $\$ 1.00$.

R. ponticum. Pontrac Rosebar. From Europe, having dark green leaves and purple flowers; $\$ 1.00$.

\section{YUCCA. Adam's Needle.}

Y. filamentosa. Thready Adav's Needle. This plant presents a majestic appearance, rising four feet in height, covered with branching panicals of large cream-white fiowers. Hardy. 


\section{VINes.}

\section{CLIMBING SHRUBS AND TRILING PLANTS.}

50 cts. each, except otherwise noted.

ATEBIA.

A. quinata. Japax Akebla. Pretty, five lobed, small and glossy, deep green leaves, with clusters of fragant and purplish flowers; 75 cts.

\section{AMPELOPSIS.}

A. quinquefolia. Virginiax Creeper. Americax Ivy. Fife oblong lonceolate leaflets, with clusters of yellowish green flowers, succeeded by bluish black berries in October; then it presents a most gorgeous appearance, as its brilliant green leaves change to the richest shades of crimson and purple. Very desirable for corering trees, walls or building; 35 cts.

ARISTOLOCHIA. Birthwood.

A. Sipho. Dutchirax's PrPz. A tall ornamental rine, with singularly curved light brown, tubular fiowers, and enormous broad, deep green leaves, which lap each other like shingles on a roof

A. tomentosa. Woolly-LeAved Binthwood. Downy, heart-shaped, light green leares, but not as large as the other; 75 cts.

CLEMATIS. Virgin's Bower.

The Clematis is a beautiful class of hardy climbers, very neat in their appearance, both flowers and foliage.

C. Flammula. Sweet-scexted Ymans's Bower. Produces large clusters of small, white. very fragrant flowers.

C. Fielena. Large, white flowers; blooms profusely early in the season.

C. Sophia. A popular variety with pale lavender-blue flowers.

C. Mirzed Seedlings. A large assortment; $35 \mathrm{cts}$.

IEDERA. IVY.

The Iry is unsurpassed for training on walls, or any place where it can show its true character.

F. Helix. InIsin on Commox Iry, Climbs walls, trees, \&c. to a great height, and adheres firmly. Leaves dark shiny green, veined with white. Thrives well when planted in a northern exposure, eren at the South. Our stock is large and very fine; $30 \mathrm{cts}$,

A. green and variegated leaved The demand has been so great, we hare procured a large assortment; for names, descriptions and prices, see Descriptive Catalogue of Plants. 
LONICERA. HONEYSCCKLE.

25 cts. each.

L. Belgicum. Moxthir Dutch Hoxeyscckle. Profuse bloomer, bearing very fragrant, red and yellow flowers.

L. flava. Tfllow Trumpet Honefscchle. Light yellow, tupe-like flowers.

I. Japonica. HALL's NEW JAPAN HoNerscckle. Sweet-scented yellow. red and white variegated flowers; will cover the ground under trees where grass will not grow, and retains its pretty leares manly through the Winter.

I. Frazerii. Frazer's Hoxerscckle, An excellent variety; yellow flowers.

L. flexuosa. Chinese Twhrirg Hoxerscckle. Peculiar, slender growth; distinct foliage, which it retains until mid-winter; rery fragrant

L. sempervirens. RED TRCurpet oR RED CoRAL. Large leares and deep red flowers.

\section{PERIPLOCA. SILK VINE.}

P. Grcea. Greclax Silk Vine. Rapid grower, with rich foliage and fine velrety white fringed flowers succeedy by silky tufted seeds.

TECOMA. TRUMPET FlOWER.

T. grandiflora. Great Trumpet Flower. A fine conspicuous variety with large orange crimson, trumpet-shaped flowers, pendulous from the ends of the branches; 75 cts.

F. radicans. AMerican Troumet Vine. A fine, strong grower, with bright scarlet, trumpet-shaped flowers, which are not as large as the former

\section{VINCA. PERTWINKLE.}

v. major variegata. A fine rariety, with broad white, striped and mottled foliage; needs protection in Winter; fine for rock-work, vases, $\& c ; 30$ cts.

\section{WISTARIA. GLYCINE.}

W. Chinensis. Chinese Wisteria. A strong grower, with pale blue flowers, in long racemes; 35 cts.

var. alba fl. pl. Double White Wistaria. New, double and very fine; $\$ 1.00$.

W. magnifica. Magnificext Wistaria. Flowers in dense drooping racemes, of a pale lilac color with conspicuous and graceful foliage; $\$ 1.00$ 


\section{Scheen, Hedgrng and Edgrng Plants.}

To raise a good and defensive hedge of Osage Orange or Honey Locust, prepare the strip of ground-say at least six feet in width-in the same manner that you would for a row of corn; set the plants four to six inches apart; cut one year plants back to two inches of the ground line, and two-year plants four to six inches, until say three or four years. The following spring, after setting, cut back to within six inches of the previous cut; then-say 15 th of July ensuing-cut eight inches above last cut, and continue to let the hedge go ahead eight inches each time of two prunings, or sixteen inches per year, until the required height is reached. Keep the sides even with large shears or brush-scythe, being careful to cut back the side branches near the top the most, which will make the hedge of sugar-loaf form, which is absolutely requisite for the maintenance of the lower branches. After the hedge is perfected, the subsequent pruning should be as near the old cuts as possible. If the hedge get too large, it can be cut back to any desired height before the buds push in spring, when it will sprout out again as vigorously as ever Another: Cut the plants as directed at the time of setting; then let them grow three to four years without any trimming; then lop them-say at about three feet from the ground. When proceeding to do the same, cut all the side branches from one side, to enable you to get at the work; then bend over the plants at the required helght in a line with the hedge, and wattle them together; then drive in refuse stakes of any kind (that will lat for two scasons) in height, just above where the plants are entwined; then wattle over the whole line of hedge two halved hop poles crossing each other between the stakes, and placed at opposite sides on the stakes, and secured by nails. This is merely to keep the plants in position until they make a growth sufficient to keep themselves; of course the stakes and poles remain in the hedge. Upright and side shoots will grow from this wattling, and the after management is the same as giren for the former plan.

\section{Evergreens.}

\section{ALL TRANSPLANTED.}

Arbor Vitæ American, " Siberian, “ Hovey's Golden, " Globosa,

Spruce Norway, “ Hemlock,

Juniper, three varieties, Dwarf Pox, rooted plants, various sizes, 12 to 48 inches, $\$ ;$ to $\$ 25$ pr 100

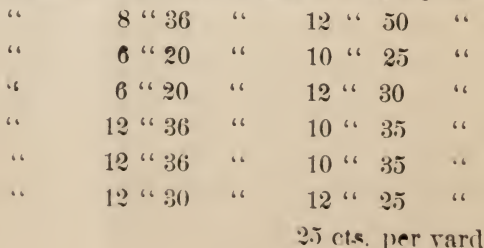




\section{DECIDUOUS.}

Obage Orange. For utility the best plant known for thls latitude. A fine stock of both one and two year plants. 1 year, $\tilde{0} 0$ cts. per $100 ; \$ 3 . \tilde{5}$ per $1000 ; 2$ years, 75 cts., per 100 ; $\$ 5$ per 1000.

Honey Locust. (GLeditschi tRIACAxthos.) 2 year plants, \$1.50 per $100 ; \$ 10$ per 100 .

Pyracantha White-berried. 1 jear, \$12.50 per 100.

Flowering Shrubs. A number of suitable varieties Irom $\$ 12$ to $\$ 25$ per 100 .

\section{WIND RREAIS.}

Our forefathers used the axe too freely, and if we want to grow fruits and vegetables in their greatest perfection, we must set belts of trees for Wind Breaks. A single line of evergreens will be sufficient in most cases, requiring but little care after three or four years. The plants can be set six to eight feet apart, and well cultivated until they get five or six feet in height, when they will take care of themselves. Among the most popular Evergreens for this purpose are Axericax Arbor Vitæ, Norway Spruce, and Scotch Prie.

\section{ROSES, CLIMEIRT.}

1 year, 30 cents; 2 years, 50 cents each.

Baltimore Belle. Pale blush, nearly white, rery double; the best white climber.

Queen of the Prairies. Bright rosy red, changing to pink, large and cupped; flowers in clusters; one of the best.

Pusseli's Cottage. C'rimson purple, striped white, fine for pillars.

Te hare a large collection of Hibrid Perpetud, Moss Roses, \&c.; for prices, descriptions and names, see Descriptive Catalogue of Plants.

\section{MISCELLANEOUS.}

Dicentra spectabilis. (EBroxeodsir DIELYTRA.) This is one of the finest, hardy Herbaceous plants in cultiration; very curious, heart-shaped, bright rose flowers, produced in long, graceful, pendant racems; rery profusc during the month of June. Leaves deeply cut and handsome; 50 cts.

Pæonias herbaceons. A large collection, embracing nearly erery shade of color and species, double, semi-double, single, and centered. They are showy, fragrant, and hardy. 25 to $50 \mathrm{cts}$, each.

Water Melon Seed. Mocvinix Sweet. The best for field culture. 65 cts. per $1 b$.

Scions, Bucis, \&. \$1.01) to $\$ 2.00$ per 100 . Few varieties at special rates. 


\section{NDEX.}

P A GE.

Abies..........................15-16

A

Arlam's Needle................. 32

E-culus........................ 20

Ailanthus.................... 20

Akebia........................ 3

1liler.......................... 20

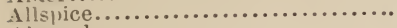

Almond.

Aln

Aithea.

Imoruha.

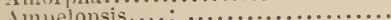

Amygitalus.

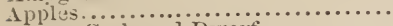
Crab and $\mathrm{D}$ warf

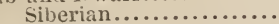

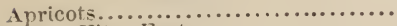

Iriour Vita, Eastern .............. 16

46 6. Japan................ 18

dristolnchia........................ 33

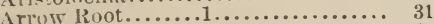

Ashberry .................... 32

1 s. $\begin{gathered} \\ 1\end{gathered}$

Ircuba ... ............... 32

B:tlm of Gilead ............... 25

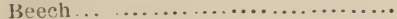

Berberis...................... 27

Вer!erry ....................... 27

Butula...................... 20

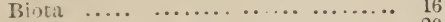

Birch ....................... 20

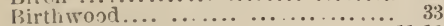

Blitekberries...................... . . .

Blatliter senna.......... ...... 23

Box.. $\quad \ldots \ldots \ldots \ldots \ldots \ldots \ldots \ldots . \ldots \ldots, 32$

Broussonetia .................. 20

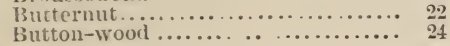

Ctlico Bush.... .............. 32

Callicarpa ......................... 27

Calycanthus.................. 28

Castanea.. ....................20-21

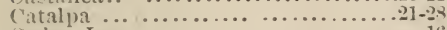

Cerlar, Incense................. 16

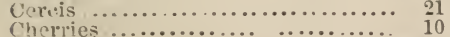

Cherries ...................... 10

Chionanthus.................. 28

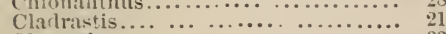

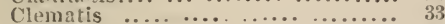

Coluteit ......................... 28

Conifera......................... 15-19

Cotton Tree...... ..........21-25

(') (1) ....................

Corylus .......................

Cranberry Tree................ 51

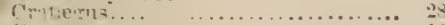

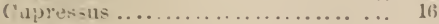

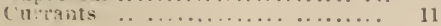

PAGE.

Currants Flowering............ 30

Cydonia....................................... ${ }^{2} 8$

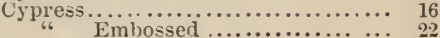

6 Deciduous................ 26

Srtissus Japan................ 17

Deciduous Shrubs..............27-31

. Trees................... 19-27

Deutzia...................... 28

Diervilla ........................28-29

Dogwood .......................... 28

Elm...................... 27

Funn

Evergreens.......................15-19

Shrubs .............. 32

Fagus....................... 21

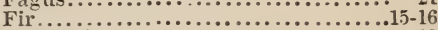

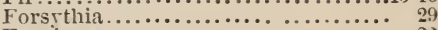

Fraxinus ...................... 22

Fruits...................... 6-15

Genista...................... 29

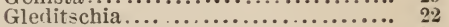

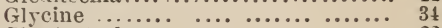

Gliptostrobus................. 22

Golden Bell...... ............. 29

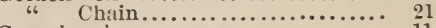

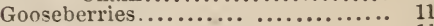

Grapes.......................... 11

Gymnocladus................. 22

Hazel........... ......... 28

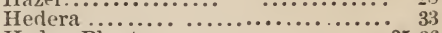

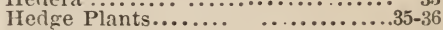

Hemlock...................... 15

Hibiscus ...................... 29

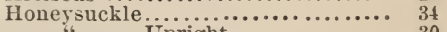

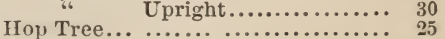

Horse Chestnut ........................ 20

"6 *6 Dwarf ............. 30

Hydrangea. .................... 29

Hypericum ................... 29

Indian Bean .................. 28

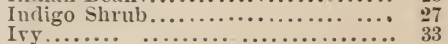

Judas Tree.................... 21

Juglaus . . .....................22-23

Juniner.................... 16

Juniperus................... 16

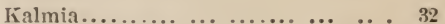

Kentucky Cofiee.................. 22

Iiolreuteria.................. 23

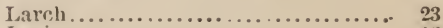

Larix . . . . . . . 
INDEX. CONTINUED.

PAGE.

PAGE.

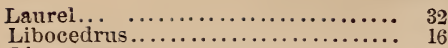

Ligustrum.. ................. 30

Lilac......................... 31

Linden.............................

Liquidamber..................... 23

Locust....... ................. $2_{22}$

Lonicera........................

Mcalura...................... 23 Magnolia................................

Mahonia ................... 32

Maiden Hair Tree.................. ${ }_{26}$

Mammouth Trees................... 17

Maple... ...................... 19

Meadow sweet $\ldots \ldots \ldots \ldots \ldots \ldots \ldots . .30-31$

Miscellaneous Fruits................ 4

Morus........................ 24

Mountain Ash...................... 25

Mulberries .......................14-24

Mulberry, Paper .................. 20

ryssa......................... 24

Oak .......................... 25

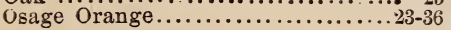

Peonia, Herbaceous.............. 36 Tree....................... 30

Paulownia $\ldots \ldots \ldots \ldots \ldots \ldots \ldots \ldots \ldots \ldots \ldots \ldots . .24$

Pavia................................ 30

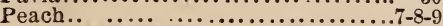

"6 Ornamental................... 9-24

Periploca....................... 34

Periwinkle......................... 34

Persica............................. 24

Philadelphus....................... 30

Pine........................... 17

Pinus........................ 17

Platanus occidentalis............... 24

Plums.......................... 9-10

Poplar.............................. ${ }_{24-25}^{9-10}$

Populus.......................24-25

Priret or Prim..................... 30

Ptelia.......................... 25

Pyrus ........................... 25

Quercus...................... 2.5

Quinces.... ...................... 10

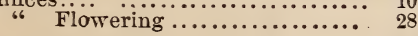

Raspberries .................. 12

Red Bud... $\ldots \ldots \ldots \ldots \ldots \ldots \ldots \ldots, 21$

Retinispora....................... 17

Rhododendron.................... 32

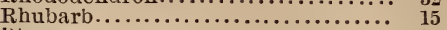

Khus........................... 30

Ribes............................ 30

Rosebay $\ldots \ldots \ldots \ldots \ldots \ldots \ldots \ldots \ldots \ldots \ldots, 3_{32}$

Rose of Sharon.................. 29

Roses, Climbing.................. 36

Salisburia....................... 26

Salix........................... $\quad 26$

Saint John's Wort................. 29

Sequora......................... 17

Silk Vine....................... 34

Snow Ball......................... 31

p pinule Tree............................29-32

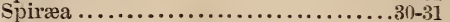

Spruce............................ 15

Strawberries......................13-14

Stuartia......................... 31

Sumach $\ldots \ldots \ldots \ldots \ldots \ldots \ldots \ldots \ldots \ldots \ldots \ldots, 30$

sweet Gum.......................

Syringa...................... $s 1$

Toxodium..................... 26

Taxus.......................... $7-18$

Tecoma........................ $3 t$

Thorne......................... 28

Thiropsis......................... 18

Thuja.............................. $18-19$

Tilia............................26-27

Trumpet Flower................. 34

Tupelo.......................... 24

Ulmus ...................... 27

Viburnum ..................... 31

Vinca.......................... 34

Vines $\ldots \ldots \ldots \ldots \ldots \ldots \ldots \ldots \ldots \ldots \ldots \ldots \ldots \ldots \ldots \ldots \ldots, 34$

Virgin's Bower.................... 33

Walnut.......................22-23

Weigelia...........................2s-29

White Fringe..................... 28

Willow.......................... 26

Wistaria.............................. 34

Yellow Wood .................... 21

Yew.............................17-18

Yucca......................... 32 


\section{LIST OF PRICES FOR SPRING, 1874.}

Any article named in the CATAloger, not priced upon this sheet, the priced will be found annexed its description in the CATALOGUE, or at the head of the division wherein it is contained:

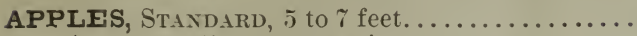

" DWARw, 25 to

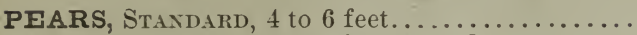

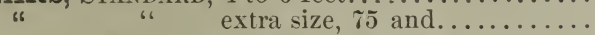

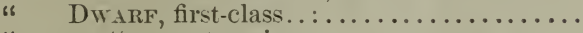

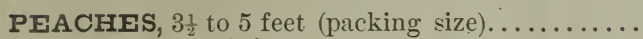

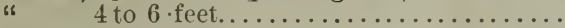

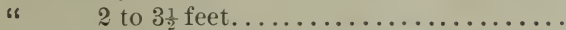

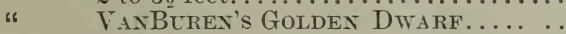

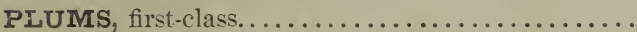

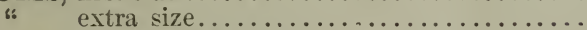

CHERRIES, STANDARd, first-class..........

extra size............

APRICOTS, NECTARINES, ALIMONDS and

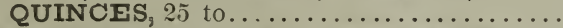

CHESTNUTS, FILBERTS, BUTTERNUTS and HOP-TREES, 50 to ....................

Grapes, Catawba, Creveling, Delaware,

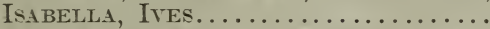

" Adirondac, Allex's Hybrid, Diaxa, Herbeyoxt, Ioxa, Israella, MabTha, Norton's Viratia, Rogen's Hybrids,

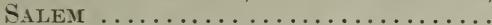

"

Crathiasa, Eumelax, Maxatawiey, Uniox Village, Walter............

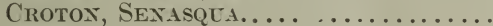

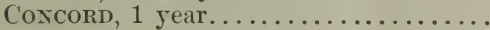
2 years......................

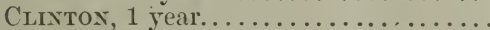

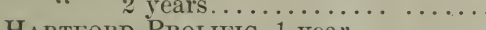
Hartford Prolific, 1 year............. 2 years.........

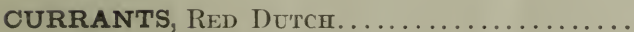
$"$ LATERSAILles.............. " Other VARIETIEs................. " extra size.

GOOSEBERRIES, HocGHTOx's SEEDLIxG...... " DOWNIYG " Exglish Varieties.............

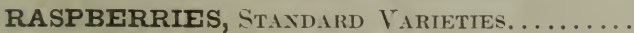
$"$ Herstixe, (new) $\ldots \ldots \ldots \ldots \ldots$ "6 BRANDYWLE. . . . . . . . . .

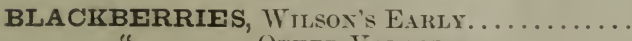
" Other Varieties.

RHUBARB.

STRAWBERRIES, WILSON'S ALBATY......... " IoxaRCH of THE WEst, (new) BRowx's WOXDER.......... "

Other Varieties..........

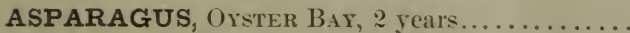
" Coxorer's Colossal, 1 year......

Each. Per 100. Per 1000. (\$ $30 \$ 2500 \$ 20000$ 3500 50 50

$60 \quad 40 \quad 00$

$\begin{array}{llll}1 & 00 & 60 & 00\end{array}$

$\begin{array}{llll}40 & 25 & 00\end{array}$

$75 \quad 5000$

$\begin{array}{llll}9 & 00 & 70 & 00\end{array}$

$\begin{array}{lllll}15 & 10 & 00 & 80 & 00\end{array}$

$\begin{array}{llll}5 & 00 & 40 & 00\end{array}$

$25 \quad 1500$

$\begin{array}{lll}60 & 40 & 00\end{array}$

55 6000

$40 \quad 30 \quad 00$

$\begin{array}{lll}50 & 35 & 00\end{array}$

50

75

25

50

75

100

15

500

4000

$\begin{array}{llll}8 & 50 & 75 & 00\end{array}$

\begin{tabular}{l}
$400 \quad 3000$ \\
\hline 50
\end{tabular}

15

$500 \quad 3500$

$\begin{array}{lllll}9 & 00 & 80 & 00\end{array}$

20. $10 \begin{array}{llll} & 10 & 100 & 00\end{array}$

Per 10. Per 10n. Per 1000.

$\$ 12 j \$ 600 \$ 5000$

$\begin{array}{llllll}1 & 25 & 6 & 50 & 55 & 00\end{array}$

$125 \div 00$

$\begin{array}{llll}1 & 75 & 10 & 00\end{array}$

$\begin{array}{llllll}1 & 50 & 6 & 00 & 50 & 00\end{array}$

$\begin{array}{llll}3 & 00 & 25 & 00\end{array}$

300

$\begin{array}{llllll}1 & 00 & 400 \quad 30 & 00\end{array}$

$\begin{array}{lllllll}1 & 50 & 8 & 00 & 50 & 00\end{array}$

$\begin{array}{llllll}1 & 00 & 400 & 3500\end{array}$

$\begin{array}{llllll}1 & 00 & 500 & 40 & 00\end{array}$

$\begin{array}{lllll}75 & 3 & 00 & 20 & 00\end{array}$

$\begin{array}{llll}1 & 00 & 5 & 00\end{array}$

$\begin{array}{rrr}1 & 00 & 500\end{array}$

$\begin{array}{llllll}1 & 25 & 6 & 00 & 50 & 00\end{array}$

$\begin{array}{llll}2 & 00 & 15 & 00\end{array}$

$\begin{array}{llll}2 & 00 & 10 & 00\end{array}$

$\begin{array}{llll}100 & 4 & 00\end{array}$

$\begin{array}{llll}1 & 00 & 4 & 00\end{array}$

$150 \quad 600$ 



\section{GREEN-IOUSES.}

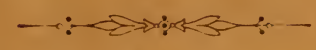

TO THOSE WHO WISH A SLPPLY OF

NEWF, RQRE AND BEAUTIFUL PLANTS,

FOR

BEDDING, STANDS, HANGING BASKETS, ROCK-WORK, \&C.,

OR TO FLRNISH

GREEN-HOUSES OR CONSERVATORIES,

WE OFFER A TERT

FXTENSIVE ASSORTMENT,

INCLUDING MANY OF THE BEST

$\rightarrow T$ T $\mathbf{T}$ I A N T $s$,

AS WE NOW HAVE OVER EIGHT THOCSAND FEET OF GLASS.

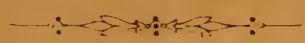

WE ALSO HAVE A FINE STOCK OF

FOREIGN GRAPE VINES

FOR GRAPERIES,

\section{P EACH TRE E}

PREPARED FOR FRUITING UNDER GLASS IN BOXES,

$$
\text { Tegetcible Plants, dec. }
$$

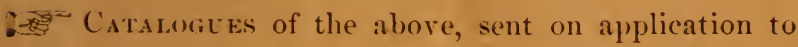

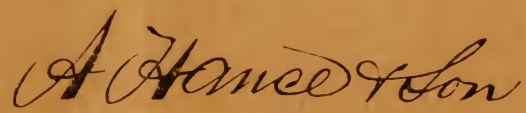

RED BANK, MONMOUTH COUNTY, N. J.

N. B. -Gilbert Howtand, of Upper Rumsom, solicits the carting and setting of trees, general gardening, care of lawns, etc. 


\section{FINE VITIA PLOTS \\ FOR SALE.}

\section{NEAR AND MDJ(INING OER NLIRERIES}

These Plots possess adrantages of

\section{HEAT'TY A NI) ITEATITI}

over all others within the same distance of the ('ity of Xrw Yon

\section{ACCESJIBLE}

by New Jersey Southern Railrnad, from Pier 2s. North Iswer, New York, and foot of Market street. Philadelphia.

\section{DISTANT}

two and a half miles from Seabright station: three and a half miles from Red Bank: or one and a half miles from Fair Haven: the latter being the nearest landing of the stenmer Ser Bird, from Jew York.

Cratontans will tind it to their interest to risit our grounds, as we are contident our stock, as well as Villa Plots, will hear inspection. 